Jurnal At-Tibyan: Jurnal Ilmu Alqur'an dan Tafsir

Volume 5 No. 1, Juni 2020 (h.38-56)

P ISSN 2442-594X | E ISSN 2579-5708

http://journal.iainlangsa.ac.id/index.php/tibyan

\title{
ANALISIS PERGESERAN SHIFTING PARADIGM PENAFSIRAN: STUDI KOMPARATIF TAFSIR ERA KLASIK DAN KONTEMPORER
}

\author{
Analysis Of Shifting Interpretation Paradigm: A Comparative Study Of Classic And \\ Contemporary Era Tafsirs
}

\author{
Wely Dozan \\ Konsentrasi Studi Qur'an Hadits \\ Pascasarjana Universitas Islam Negeri Sunan Kalijaga Yogyakarta \\ welydozan77@gmail.com

\begin{tabular}{|l|l|l|}
\hline \multicolumn{2}{|c|}{ DOI: 10.32505/tibyan. v5i1.1631 } \\
\hline Submitted: 06-11-2019 & Revised: 24-06-2020 & Accepted: 27-06-2020 \\
\hline
\end{tabular}

\begin{abstract}
This paper aims to explore the paradigm shift in the interpretation of the Qur'an in the classical and contemporary eras in the path of interpretation of Ibn Kathir and Fazlur Rahman. The focus in this study examines the causes of shifts in interpretation and contextualization of the interpretation model. The type of research is library research so that in this study using qualitative (descriptive-analytical) research, it is research that describes the object to be critically examined, and looks for the roots of the character's thoughts. The approach that I want to use in this study is historical-analytical, that is, according to historical roots analytically the shift in interpretation occurs. The results of this study indicate that, the interpretation of interpretation in the classical and contemporary era of interpretation is caused by the shifting paradigm, namely the birth of a new methodological concept to prove the suitability between text and social relaity. The argumentation of Ibn Katsir's interpretation of the "Classical Era" The main characteristic of his interpretation model is the textual pattern based on the interpretation of bil ma'tsur. Second, the interpretation of Ar-ra'yi. While Fazlur Rahman "Contemporary Era" can prove interpretation as an effort to solve problems in answering various challenges of the times. This is due to the emergence of a variety of interpretive approaches including: contextual orientation in interpretation, interpretation as social transformation, and gender analysis as an effort to seek justice.
\end{abstract}

Keywords: Paradigm Shifting, Interpretation, Classic, Contemporary.

Hak Cipta @ 2020. Dimiliki oleh Penulis, dipublikasikan oleh Jurnal At-Tibyan: Jurnal Ilmu Alqur'an dan Tafsir.

Artikel dengan akses terbuka. Lisensi: CC-BY

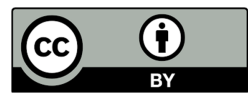




\begin{abstract}
Abstrak
Tulisan ini bertujuan untuk mengeksplorasi pergeseran paradigma penafsiran Al-Qur'an pada era klasik dan kontemporer dalam lintasan penafsiran Ibnu Katsir dan Fazlur Rahman. Fokus dalam penelitian ini meneliti sebab-sebab terjadinya pergeseran penafsirannya dan kontekstualisasi model tafsirnya. Jenis peneilitian yaitu penelitian kepustakaan (library research) sehingga dalam penelitian ini menggunkaan penelitian kualitatif (deskriptif-analitis), merupakan penelitian yang mendeskripsikan tentang objek yang akan diteliti secara kritis, serta mencari akar-akar pemikiran tokoh tersebut. Adapun pendekatan yang hendak penulis gunakan dalam penelitian ini adalah historis-analitis, yaitu dengan menurut akar-akar historis secara analitis terjadinya pergeseran penafsiran. Hasil penelitian ini menunjukkan bahwa, pergseseran penafsiran dalam lintas tafsir era klasik dan kontemporer disebab shifting paradigm yaitu lahirnya konsep metodologis baru untuk membuktikan kesesuaian antara teks dan relaitas sosial. Argumentasi tafsir Ibn Katsir "Era Klasik" ciri khas utama model tafsirnya adalah bercorak tekstual yang didasarkan pada tafsir bil ma'tsur. Kedua, tafsir Ar-ra'yi. Sedangkan Fazlur Rahman "Era Kontemporer" dapat membuktikan tafsir sebagai salah satu upaya untuk memecahkan problematika dalam menjawab berbagai persoalan tantangan zaman. Hal ini disebabkan oleh munculnya keragaman pendekatan tafsir diantaranya: orientasi kontekstual dalam penafsiran, tafsir sebagai tranformasi sosial, dan analisis gender sebagai upaya mencari keadilan.
\end{abstract}

Katakunci: Shifting Paradigma, Tafsir, Klasik, Kontemporer.

\title{
Pendahuluan
}

Melacak dari akar sejarah awal penafsiran ayat al-Qur'an sebenarnya sudah dilakukan mulai sejak zaman Nabi Muhammad Saw hingga kian kini tetap saja penafsiran masih berlangsung. Hal ini menunjukkan bahwa, dinamika dan perkembangan penafsiran al-Qur'an terjadi reformasi untuk mencari arah baru dalam proses pencarian makna dibalik teks ayat al-Qur'an tersebut. Secara historis, perkembangan tafsir al-Qur'an di era klasik menggunkan berbagai tren penafsiran mulai dari penafsiran al-Qur'an secara Ijmali (Global), Ananilis (Tahlili), Perbandingan (Muqarran), dan tematik (Maudhu'i) yang biasa dilakukan dalam menafsirkan ayat alQur'an untuk menemukan makna subtansial yang terkandung didalamnya teksnya. ${ }^{1}$

Hal tersebut menunjukkan bahwa, indikasi dan kecenderungan penafsiran alQur'an era klasik masih berorientasi pada pemahaman secara tekstual tanpa menimbangi makna kontekstual. Namun demikian, tafsir pada era kontemporer telah melakukan rekonstruksi metodologis baru sebagai alat analisa dalam dunia penafsiran. Jadi, apapun itu, kalau ingin memahami al-Qur'an dengan benar, maka tidak bisa lepas

${ }^{1}$ Wely Dozan, “Epistemologi Tafsir Klasik: Studi Analisis Pemikiran Ibnu Katsir”, Jurnal: Falasifa 10, 1 (2019): 147-159 
dengan serangkaian ilmu-ilmu terdahulu melainkan butuh metodologi saintifik sebagai pengungkapan terhadap teks ayat al-Qur'an. ${ }^{2}$

Oleh karenanya, dalam memahami al-Qur'an diperlukan metode dan pendekatanpendekatan untuk menafsirkan al-Qur'an yang dapat memberikan jawaban yang pas dan sesuai dengan sekian banyak persoalan yang berkembang di masyarakat. Jawaban tersebut yang sesuai dengan apa yg dibutuhkan dan dirasakan masyarakat pada saat ini sangat berarti dan berdampak positif bagi Islam yang dikenal sebagai Agama rahmattalil alamin. Dalam perkembanganya metode-metode yang digunakan para mufassir banyak dan sangat beragam namun hal itu terjadinya perbedaan dalam memberikan penafsiran terhadap ayat al-Qur'an. ${ }^{3}$

Lebih-lebih dalam pemikiran kontemporer saat ini munculnya berbagai persoalan dan berbagai macam pemikiran yang sekian menantang dalam menjawab sebuah pokok permasalahan, hal ini dapat melahirkan kajian baru terhadap penafsiran al-Qur'an yang mengandung nilai historis, yaitu bahwa wahyu itu diturukan oleh Tuhan dalam sejarah. Dengan kata lain bahwa al-Qur'an bersifat meta-historis sebagai kalam wujud Allah Swt, sekaligus bersifat historis karena menggunakan bahasa yag kultural, lokal dan partikular serta telah memasuki wilayah historis dan mengalami interaksi dialektis dengan realitas budaya selama proses pewahyuan. ${ }^{4}$

Maka dalam hal ini, Muhammad Syahrur berpendapat, relaitas historis menunjukkan bahwa setiap generasi memberikan interpretasi al-Qur'an yang memancar dari relaitas yang muncul dan sesuai dengan kondisi dimana mereka hidup. Ini menujukkan adanya keserasian dan memberikan pemahaman baru yang tentu berbeda dengan mainstream yang selama ini berkembang. ${ }^{5}$ Harus diakui bahwa dinamika kajian al-Qur'an memang sangat luiar biasa. Berbagai kajian al-Qur'an secara intensif juga dilakukan di era modern maupun kontemporer salah satunya Muhammad Syahrur yang mencoba merekontruksi metodologi penafsiran al-Qur'an dikenal istilah hermeneutika. ${ }^{6}$

Shifting paradigm merupakan salah satu konsep yang melatarbelakangi pergeseran tafsir, dan tentu hal ini penulis akan melakukan pencarian akar sejarah penafsiran alQur'an mulai era klasik dan kontemporer untuk memetakkan secara signifikan proses pergeseran penafsiran sekaligus memberikan kontekstualisasi dan gaya penafsiran secara mendalam yang diambil dari penafsiran Ibn Katsir dan Fazlur Rahman. Konsep paradigm merupakan konstruk berpikir yang mampu menjadi wacana untuk

\footnotetext{
${ }^{2}$ Munawwir Husni, Studi Keilmuan Al-Qur'an, (Yogyakarta: Binafsi Publisher, 2015), 5.

${ }^{3}$ Ahmad Fadlol dkk, Studi Al-Qur'an Teori dan Metodologi, (Yogyakarta: Idea Press, 2011), 160.

${ }^{4}$ Wely Dozan, “Hermeneutika Sebagai Metode Penafsiran Al-Qur'an: (Melacak Teori Hermeneutika Fazlurrahman)”, Jurnal: El-Hikam 12, 1 (2019): 155-181.

${ }^{5}$ Ahmad Zaki Mubarok, Pendekatan Strukturalisme Linguistik Dalam Tafsir al-Qur'an Kontemporer"ala" Muhammad Ayahrur, (Yogyakarta: Elsaq Press, 2007), 201.

${ }^{6}$ Abdul Mustaqim, Dinamika Sejarah Tafsir Al-Qur'an "Studi Aliran-Aliran Tafsir Dari Periode Klasik Hingga Kontemporer” (Yogyakarta: LSQ Ar-rahmah), 151.
} 
menemukan keilmiahan yang terdapat dalam konseptualisasi menjadi wacana untuk menemukan ilmiah atau revolusi yang baru. ${ }^{7}$

Dengan demikian, tulisan ini hadir untuk mengeksplorasi proses pergeseran pradigma penafsiran mulai dari klasik "Ibn Katsir" dan kontemporer "Fazlur Rahman" yang selama ini menurut hemat penulis terjadi dinamika dan pradigma dalam penafsiran, baik dari segi pemahaman terhadap al-Qur'an, metodologi penafsiran secara tekstual menuju kontekstual, pendekatan sejarah dan sosial, untuk mendekati Al-Qur'an bukan hanya saja melalui teks semata melainkan adanya pemahaman dibalik teks bahwa kitab suci al-Qur'an tetap cocok untuk dijadikan petunjuk di mana saja dan kapan saja yakni (shalihun likulli zammani wa makkani). ${ }^{8}$

\section{Tinjauan Umum Shifting Paradigm Dalam Lintasan Tafsir}

Seiring dengan perkembangan zaman yang terus berubah, pada kenyataannya ilmu pengetahuan mengalami perkembangan dan pergeseran teori dalam penggal waktu tertentu. Sebab kontsruk teoritis ilmu pengetahun yang merupakan produk zaman tertentu tidak secara universal berlaku dan cocok untuk zaman berikutnya yang nota bene memiliki karakteristik kesejarahan yang berbeda dengan waktu dan tempat di mana konstruksi itu pertama kali dibangun. Shifting paradigm merupakan salah satu teori ilmu pengetahuan yang membahasan tentang pola pikir dan perkembangan ilmu pengetahuan dari masa kemasa untuk memperlihatkan gambaran dan dimensi kreatif manusia atau ide-ide yang lain terus menimbulkan peradaban manusia ke arah satu dengan lainnya. ${ }^{9}$

Dalam perspektif Thomas S. Kuhn, seorang ilmuan pada prinsipnya bekerja dengan paradigma tertentu. Paradigm itu memungkinkan sang ilmuan untuk memecahkan kesulitan yang muncul dalam rangka ilmunya hingga menemukan banyak anomali yang tidak dapat dimasukkan dalam kerangka berpikir, dan menunt ut revolusi pragmatik. Kuhn meringkas pola-pola kerangka pragmatik diantarannya sebagai berikut: Pertama, cara memandang sesuatu. Kedua, dalam ilmu pengetahua: model, pola, ideal. Dari model-model dan sebuah fenomena yang dipandang dan dijelaskan. Ketiga, Dasar untuk menyeleksi problem-problem dan pola untuk memecahkan problem-problem riset.

Dengan demikian, konsep paradigm merupakan konstruk berpikir yang mampu menjadi wacana untuk menemukan keilmiahan yang terdapat dalam konseptualisasi menjadi wacana untuk menemukan ilmiah atau revolusi yang baru. ${ }^{10}$ Secara teoritis paradigma pada dasarnya adalah teori yang memperbincangkan terkait proses perkembangan berpikir dan pengaruhnya terhadap pengetahuan. Gagasan ini ingin

\footnotetext{
${ }^{7}$ Thomas S. Kuhn, The Structure of scientefic Revolution (Chicago: Univesity of Chicago Press, 1996), 43

${ }^{8}$ Rohimi Metodologi Ilmu Tafsir \& Aplikasi Model Penafsiran (Yogyakarta: Pustaka Pelajar, 2007), 46.

${ }^{9}$ Zubaidi, Filsafat Barat "Dari Logika Baru Rene Descartes hingga Revolusi Sains ala Thomas Khun, (Jogjakarta: AR-RUZZ MEDIA, 2007), 200.

${ }^{10}$ Ayi Sofyan, Kapita Selekta Filsafat, 158-157.
} 
menegaskan bahwa teori ilmiah tidak hanya terbatas pada serangkaian prinsip teoritis, namun ia juga mencakup pandangan dunia dalam ilmu pengetahuan dan hal itulah yang kemudian diinisiasi oleh Kuhn sebagai "paradigma". Untuk memahami paradigma. ${ }^{11}$

Kaitanya terhadap tafsir bahwa, shifting paradigm berupaya untuk menganalisa bagaiaman kemudian melihat terjadi pergeseran dan sebab-sebab bagaiaman konstruk berpikir ulama tafsir ketika memahami dan menafsirkan makna teks tersebut. Shifting paradigm dapat memberikan konsep untuk menemukan anomali-anomali yang kemudian mengalami puncak krisis. Disitulah kemudian terdapat paradigma baru sebagai alternatif pertama atau tetap pada paradigma lama sebagai alternatif kedua. Maka bisa saja paradigma lama tetap digunakan setelah munculnya paradigma baru. ${ }^{12}$

\section{Perkembangan Shifting Paradigm Tafsir Era Klasik}

Melacak dari akar penafsiran al-Qur'an sebenarnya sudah berkembang pada peroide klasik yang dimana pada periode klasik di identik dengan penafsiran mulai dari Nabi Saw, Sahabat sampai dengan tabi'in yang pada waktu itu penafsiran al- Qur'an masih bersandarkan pada hadits Nabi Saw dan riwayat para sahabat. ${ }^{13}$ Pasca wafatnya Nabi Saw lebih-lebih kaum muslim dalam memahami ayat al-Qur'an terjadi banyak kekurangan dalam memahami teks ayat al-Qur'an dan semenjak itulah demi sedikit penafsiran al-Qur'an selalu berkembang. ${ }^{14}$

Pada masa tabi'in penafsiran al-Qur' an bukan hanya menafsirkan al-Qur' an secara spesipik melainkan al-Qur'an ditafsirkan secara analisis melai melacak berbagai aspek pendekatan keilmuan dalam bahasa al-Qur'an. Adapun klasifikasi model penafsiran alQur'an pada umumnya dapat diklasifikasikan sebagai berikut:

1. Tafsir Tahlili, yaitu tafsir yang berusaha menguraikan kata-kata menuturkan bahasa, I'rab dan balaghah dan qira'at, yang mengkaji berbagai aspeknya terkait asbabun nuzul qur'an disertai dengan mengaitkan antar ayat, kemudian menjelaskan makna dan hikmahnya secara terperinci. ${ }^{15}$ Tafsir pendekatan tahlili mencoba para mufassir untuk menafsirkan sebatas tekstual dan dukungan dari para riwayat para sahabat dan tabi'in

2. Tafsir Ijmali, yiatu menafsirkan ayat al-Qur'an secara global. Penafsiran ini menurut para mufassir berupaya untuk menjelaskan makna-makna al-Qur'an dengan uraian singkat dan bahasa yang mudah dan lugas. Sehingga metode

\footnotetext{
${ }^{11}$ Thomas S. Kuhn, The Structure of scientefic Revolution (Chicago: Univesity of Chicago Press, 1996), 43

${ }^{12}$ Siti Robikah, "Shifting Paradigm Dalam Tafsir Al-Quran ; Analisis Terhadap Perkembangan Tafsir Feminis Di Indonesia”, Jurnal: Tafsere 7, no. 2 (2019): 42-72.

${ }^{13}$ Abdul Mustaqim, Dinamika Sejarah Tafsir Al-Qur'an "Studi Aliran-aliran Tafsir dari Periode Klasik, Pertengahan, hingga Moderen-Kontemporer", 40.

${ }^{14}$ Yayan Rahtikawati, Dadan Rusman, Metodologi Tafsir Al-Qur'an 'Struturalisme, Semantik, Semiotik, \& Hermeneutik (Bandung: Pustaka Setia, 2013), 32

${ }^{15}$ Yunus Hasan Abidu, Tafsir Al-Qur'an (Sejarah Tafsir dan Metode Para Mufassir) (Jakarta: GAYA MEDIA PRATAMA, 2007), 3.
} 
tersebut dapat memberikan pemahaman terhadap semua orang yang berpengetahuan sekedarnya. 16

3. Tafsir Muqarran, yaitu menjelaskna ayat al-Qur'an dan menguraikanya dengan menyebutkan pendapat para mufassir, mengemukakan pendapat mereka lalu membandingkan antara yang satu dengan yang lainya untuk menggali maknanya, hukumnya, dan pesan moral yang termuat dalam berbagai penafsiran tersebut. ${ }^{17}$

4. Metode Maudhu'i, yaitu menafsirkan ayat Al-Qur'an denagn menghimpun ayatayat dengan memiliki tema yang sama, menjelaskanya secara menyeluruh, melengkapinya dengan hadis-hadis dengan tema yang sama yang termuat dalam ayat al-Qur'an. ${ }^{18}$

Hal tersebut yang dilakukan oleh mufassir kalsik dalam rangka mencari sebuah kejelasan terhadap teks yang terkandung di dalam al-Qur'an. Sehingga pada dasarnya perkembangan proses penafsiran al-Qur'an era klasik pada masa tabi'in tidak pernah terlepas dari Hadis Nabi dan riwayat sabahat yang lainya. ${ }^{19}$ Seiring dengan meluasnya keilmuan. Hal ini menujukkan bahwa penafsiran bukan hanya sebatas riewayat dari pendapat para sahabat. melainkan para ulama menggunkan pendekatan tafsir ar-Ra'yi yang didasarkan pada rasional dan pemikiranya.

Menurut hemat penulis, penafsiran al-Qur'an yang dilakukan oleh mufassir era klasik sebenasrnya dapat diringkas menjadi beberapa aspek secara garis besar yaitu Tafsir Bil Al-Matsur dan Tafsir Ar-Rayi. ${ }^{20}$ Adapun penafsiran yang bersifat Bil Ma'tsur adalah penafsiran yang dilakukan oleh para ulama memiliki beberapa aspek secara garis besar diantaranya, Pertama, penafsiran al-Qur'an dengan al-Qur'an. Kedua, Penafsiran Al-Qur'an dengan hadis. Ketiga, penafsiran al-Qur'an dengan pendapat para sahabat. Keempat, penafsiran al-Qur'an dengan pendapat para tabi'in. Yang termasuk penafsiran bil ma'tsur diantaranya, Ibn taimiyah (661-728 H/12621327 M). Ibn Katsir (701-774 H/1301-1372 M) menyatakan bahwa, "Sekiranya ada orang yang bertanya tentang penafsiran al-Qur'an dengan al-Qur'an. Dan jika hendak tidak menemukanya maka menafsirkan al-Qur'an dengan pendapat hadis atau sunah Nabi Saw. Hal ini yang dilakukan oleh mufassir klasik dalam menafsirkan ayat alQur'an. ${ }^{21}$ Adapun pemetaan penafsiran ayat al-Qur'an Bil Ma'tsur yang dilakukan oleh ulama klasik di bawah ini sebagai berikut:

\footnotetext{
${ }^{16}$ Abd. Al-Hayy Al-Farmawi, Suatu Pengantar Metode Tafsir Maudhu'I (Bandung: Pustaka Setia, 2002), 38

${ }^{17}$ Abdul Mustaqim, Metode penelitian al-Qur'an dan Tafsir(Yogyakarta: Idea Press, 2012), 19

${ }^{18}$ Mustaqim, Metode penelitian al-Qur'an dan Tafsir, 3.

${ }^{19}$ Abdul Mustaqim, Dinamika Sejarah Tafsir Al-Qur'an, 84.

${ }^{20}$ Usman, Ilmu Tafsir, (Yogyakarta: Teras, 2009), 282.

${ }^{21}$ Ahmad Izzan, Metodologi Ilmu Tafsir, (Tafakkur: Humaniora, 2011), 67.
} 


\section{Tafsir Bi Al-Riwayah}

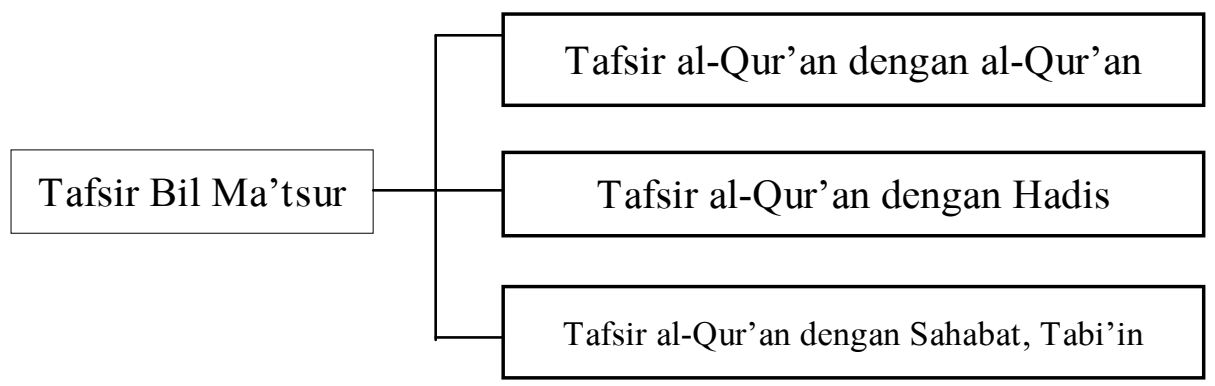

Pemetaan tersebut menunjukkan kerangka shifting paradigma dan bentuk penafsiran al-Qur'an yang berkembang era klasik jadi dapat disimpulkan bahwa penafsiran klasik cnrung memahami ayat al-Qur'an secara teks. Namun perkembangan penafsiran al-Qur'an selalu mengalami dinamika kaitanya terhadap penafsiran alQur'an Bil Ra'yi yang dimana penafsiran al-Qur'an bi al-Ra'yi di identik dengan sebuh penafsiran yang mengacu kepada akal pikiran dan rasional.

Menururt Abd. Al-Hayy Al-Farmawi yang menjelaskan secara spesipik bahwa, penafsiran Ar-Ra'yi merupakan menafsirkan al-Qur'an dengan Ijtihad setelah mufassir bersangkutan mengetahui metode yang digunakan orang-orang Arab beserta muatan artinya. Untuk menafsirka ayat tersebut secara rasinolan bukan berarti berlandaskan ilmu pengetahhuan, melainkan juga ilmu kaidah kebahasaan al-Qur'an, misalnya, Asbabun Nuzul Qur'an, Nasikh Mansukh, Ilmu Nahwu Sharaf, Ilmu Ushul Fiqh, sebagaimana yang dituturkan pada penjelasan tentang syarat-syarat menjadi mufassir tersebut. ${ }^{22}$ Sehingga dapat disimpukan bahwa, sejarah penafsiran al-Qur'an mulai era awal yakni periode klasik dapat diklasifikasikan sebagai berikut yaitu, Pertama, Tafsir Bil Ma'tsur, Kedua, Tafsir Ar-Ra'yi.

\section{Pergeseran Shifting Paradigma Tafsir Kontemporer}

Sebelum kita mengkaji proses pergeseran pradigma penafsiran al-Qur'an baik dari era klasik sampai dengan kontemporer yang perlu penulis bahas disisni adalah bagaiaman pemahman al-Qur'an diera kontemporer ini sehingga dibab berikutnya dapat membandingkan proses pradigma penafsiran ayat al-Qur'an sampai era kontemporer.

Al-Qur'an diera kontemporer sebenarnya telah mengalami perbedaan pemahaman. Lebih-lebih al-Qur'an bukan hanya sebatas dikaji secara teks atau makna secara literlek, melainkan al-Qur'an perlu dikaji dari kontekstual. Lebih-lebih bersentuhan dengan epistemologi modernitas, sehingga merubah persepsinya tentang al-Qur'an dan proses interpretasi. ${ }^{23}$

\footnotetext{
${ }^{22}$ Abd. Al-Hayy Al-Farmawi, Suatu Pengantar Metode Tafsir Maudhu'i, 26.

${ }^{23}$ Mansur, Metodologi Tafsir Kontemporer (Menimbang Tawaran Metodologi Tafsir Emansipatoris) (Yogyakarta: Interpena, 2011), 7.
} 
Proses interpretasi tersebut dimulai bahwa, teks ayat al-Qur'an bukan berhenti sebatas teks. Maka Fazulrrahman dalam hal ini memahami al-Qur'an sebagai bukan ditafsirkan secara langsung melainkan al-Qur'an perlu dibaca dari latar belakang turunya al-Qur'an atau konteks historis yang oleh para mufassir disebut sebagai asbab al-nuzul (sebab-sebab pewahyuan). Kesejarahan al-Qur'an sangat penting untuk dilakukan dalam menafsirkan melalui pendekatan historis-kronologis. ${ }^{24}$

Jika ditelusuri lebih jauh lagi, maka konteks asbabun nuzul Qur'an sebenarnya dapat dilklasifikasikan menjadi dua aspek diantaranya, Pertama, Asbabun Nuzul Qur'an mikro 1. Kedua asbabun nuzul Qur'an mikro 2. Ananlisis tersebut yang digunakan penafsiran dalam menafsirkan al-Qur'an secara kontekstual. Pelacakan terhadap ayat al-Qur'an melalui mikro 1 menekankan pada bahawa, ayat al-Qur'an perlu dilihat dari faktor turunya sebuah ayat lalu bagaiaman konteks al-Qur'an tersebut dikaitkan dengan kondisi kekinian. Konteks tersebut memiliki beragam elemen yang mencakupi misalnya, tempat tinggal, budaya, agama, dan politik sebagainya. ${ }^{25}$

Maka dalam konteks penafsiran kontemporer mennggap bahwa al-Qur'an sebenarnya tetap eksis berbicara sesuai tempat dan waktu dengan istilah "shalihun likulli zamann wa makann" ditempat sesuai keadaan agar pemahaman terhadap alQur'an tidak berhenti sebatas teks melainkan perlu ditelusuri makna ayat al-Qur'an dibalik teks ayat tersebut. Jadi membaca teks, dalam pengertian memahaminya mengandung penafsiran dan penakwilanya. Pemahaman bersifat langsung, tanpa ,membutuhkan penafsiran atau penakwilan. Jika pemahaman lanngsung sulit maka hal ini salah satu metodologi yang akan dibutuhkan memahami dari tingkat kedua dengan berlandaskan pada logika bahasa, orientasi teks (konteks) keharusan sikap atau semangat zaman tersebut. ${ }^{26}$

Maka dalam penafsiran kontekstual dapat dikatakan sebagai proses interpretasi yang melalui hermeneutika. Hal ini menurut penulis, penting untuk di singgung dan dikaji teori hermeneutika dalam penafsiran. Metode tersebut dapat membeikan pemahaman baru dalam penafsiran al-Qur'an baik dalam konteks sejarah maupun konteks sosial. Karena hermeneutika mencoba mencari pemahaman terkiat dibalik teks ayat tersebut. Sejalan dengan kebutuhan dan tantangan akan suatu metode penafsiran yang bercorak kontekstual. Sebagaiamana dipandang bahwa, metode penafsiran cukup resrepentatif dan komprehensif untuk mengolah teks serta sangat intensif dalam menggarap kontekstualisasi. ${ }^{27}$

Bisa dikatakan, tugas pokok hermeneutika ialah bagaimana menafsirkan sebuah teks klasik atau teks yang asing sama seklai yang menjadi milik kita yang hidup di zaman dan tempat serta suasana kultural yang berbeda. Oleh karenanya, dapat diakui

\footnotetext{
${ }^{24}$ Taufik Adnan Rahkmat, Islam dan Tantangan Modernitas (Studi atas Pemikiran Hukum Fazlurrahman) (Bandung: Mizan, 1989), 158.

${ }^{25}$ Abdullah Saed, Al-Qur'an Abad 21 “Tafsir Kontekstual” (Bandung: Mizan, 2016), 39.

${ }^{26}$ Hasan Hanafi, Hermeneutika Al-Qur'an, Penerjemah: Yudian Wahyudi, Hamdiah Latif (Yogyakarta: Pesantren Nawesea Press, 2009), 74-75.

${ }^{27}$ Fahruddin Faiz, Hermeneutika Al-Qur'an, (Yogyakarta: Qalam, 2007), 8.
} 
bahwa adalah cara paling tepat untuk menafsirkan al-Qur'an dan mennjelaskan makna-makna dari wacana lisan dan bahasa gerak dalam ritual. ${ }^{28}$ Dalam hal ini penulis akan memetakkan secara signifikan terkait perkembangan penafsiran al-Qur'an kontemporer sebagai berikut.

\section{Struktur Epistemologi Tafsir Era Reformatif Dengan Nalar Kritis}

\begin{tabular}{|l|l|l|l|}
\hline Sumber Penafsiran & $\begin{array}{l}\text { Metode dan } \\
\text { Pendekatan }\end{array}$ & Validitas Pennafsiran & Tujuan penafsiran \\
\hline $\begin{array}{l}\text { Al-Qur'an, } \\
\text { Relaitas,akal, yang } \\
\text { berdialektika secara } \\
\text { sirkular, fungsional }\end{array}$ & $\begin{array}{l}\text { Bersifat } \\
\text { Interdisipliner, mulai } \\
\text { hermeneutic, } \\
\text { lingustik. }\end{array}$ & $\begin{array}{l}\text { Hubungan antara hasil } \\
\text { penafsiran dengan } \\
\text { proposisi sebelumnya }\end{array}$ & $\begin{array}{l}\text { Kritis, } \\
\text { transformatif, } \\
\text { solutif, ideologis, }\end{array}$ \\
\hline
\end{tabular}

Berdasarkan struktur di atas, menunjukkan adanya proses pergeseran penafsiran pradigma penafsiran al-Qur'an era klasik dan kontemporer. Mulai dari epistemologi penafsiran, terkait dengan pendekatan histori dan sosial dan cendrung melihat bagaimana masyarakat merespon tehadap ayat al-Qur'an. Untuk lebih jelas dalam melihat proses pergeseran pradigma penafsiran. Maka penulis akan mengananalisis bagaimana model penafsiran al-Qur'an era klasik dan kontemporer di antara beberapa ayat yang selama ini menjadi problematika dalam proses penafsiranya. Tentu hal ini yang menjadi bahan analisis dalam pembahasan selanjutnya.

\section{Analisis Pergeseran Shifting Pradigma Penafsiran Al-Qur'an Klasik Dan Kontemporer}

Pada pembahasan ini,penulis akan mencoba untuk membongkar salah satu kajian tafsir tematik hal ini kaitanya dengan problematika yang sering dihadapi dalam dunia penafsiran yaitu terkait dengan masalah isu gender yakni poligami yang selama ini tiada henti untuk diperbincangkan dalam proses penafsiran. ${ }^{29}$ Menurut hemat penulis penafsiran ayat poligami terjadi pergeseran sekaligus perpindahan metodologi penafsiran al-Qur'an. Shifting paradigm sebagai salah satu upaya untuk melihat terjadinya pergeseran tafsir Ibn Katsir dan Fazlurrahman.

\section{Kontekstualisasi Penafsiran Ibnu Katsir “ Tafsir Era Klasik”}

Penafsiran ayat poligami dalam berbagai penafsiran sering terjadi pro-kontra dalam penafsiran. Hal tersebut menunjukkan bahwa, poligami secara tektual dalam ayat tersebut tidak ada istilah untuk menunjukkan larangan. Membaca kembali ayat poligami di dalam al-Qur'an, konteks ayat tersebut sebenarnya tidak ada yang menunjukkan larangan, Bukankah poligami ada di dalam al-Qur'an. Melarang poligami berarti melarang apa yang diperintahkan al-Qur'an. Demikian ini ungkapan yang sering

\footnotetext{
${ }^{28}$ Rohimi, Metodologi Ilmu Tafsir dan Aplikasi Model Penafsiran (Yogyakarta: Pustaka Pelajar, 2007), 59 .

${ }^{29}$ Abdul Mustaqim, Epistemologi Tafsir Kontemporer(Yogyakarta: LKiS, 2010), 257.
} 
menampar muka pada setiap pembicaraan mengenai perlunya pernikahan terhadap perempuan dalam membaca ayat poligami. ${ }^{30}$

Jika menelusuri buku-buku klasik, ditemukan bahwa sesuatu yang ada di dalam al-Qur'an tidak diterapkan begitu saja, tetapi dibaca dengan dampingan ayat-ayat lain dan hadis-hadis serta dengan menggunakan bantuan ilmu bahasa dan ilmu-ilmu lain ${ }^{31}$. Karena secara historis perkembanagan penafsiran ulama klasik cenderung memahami dan menafsirkan al-Qur'an secara teks, sehingga penafsiranya masih bersifat parsial dan kurang mendetail dalam menafsirkan suatu ayat, sehingga kadang sulit mendapatkan gambaran utuh mengenai pandangan al-Qur'an sesuatu masalah tertentu. ${ }^{32}$

Terkait dengan penafsiran Q.S. an-Nisa' 4: 3 yang berbunyi:

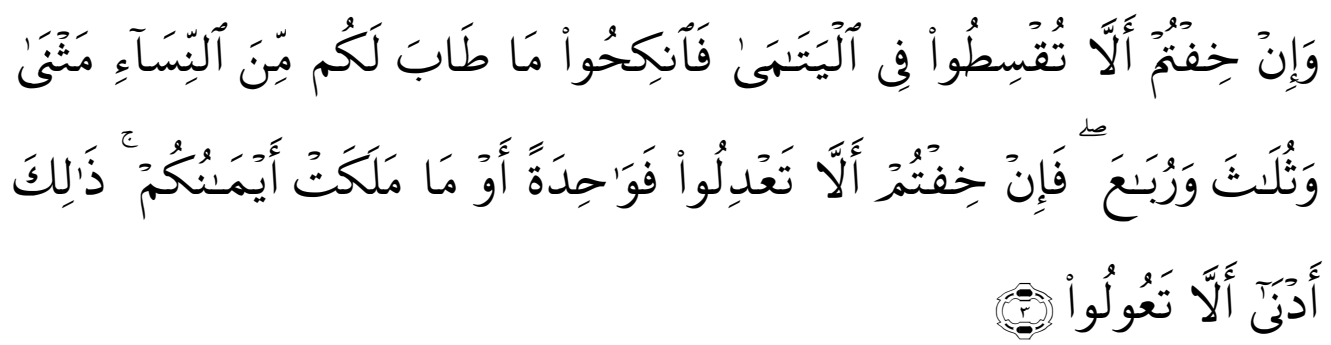

Artinya: "Dan jika kamu khawatir tidak akan mampu berlaku adil terhadap (hak-hak) perempuan yatim (bila mana kamu menikahinya), maka nikahilah perempuan (lain) yang kamu senangi dua, tiga, atau empat. Tetapi jika kamu khawatir tidak akan mampu berlaku adil maka nikahilah seseorang saja atau hamba sahaya perempuan yang kamu miliki yang demikian itu lebih dekat agar kamu tidak berbuat zalim". (Q.S. an-Nisa'[4]: 3). ${ }^{33}$

Selama ini, cenderung dipahami sebagai ayat poligami, Secara tekstual memang ada ayat yang membolehkan praktik poligami diantara beberapa penafsiran. Akan tetapi dalam penafsiran tersebut tentu sangat beragam. Salah satu contoh dari penafsiran ulama klasik yaitu Ibnu Katsir dalam tafsirnya bahwa, konteks tersebut adanya terjadi kebolehan dalam berpoligami selama mampu berbuat adil terhadap istri. Hal ini sebagaiaman yang diucapkan oleh Ibnu Abbas dan jumhur ulama, karena konteks ayat adalah menyebutkan nikmat dan diperbolehkan. Sehingga ibnu katsir

\footnotetext{
${ }^{30}$ Mansur, Metodologi Tafsir Kontemporer, (Menimbang Tawaran Metodologi Tafsir Emansipatoris), (Yogyakarta: Interpena, 2011), 32.

${ }^{31}$ Adapun maksud ilmu bahasa dan ilmu yang lainya dibutuhkan dalam penafsiran seorang mufassir diantaranya: Pertama, Ilmu bahasa Arab (Linguistik). Dengan ilmu ini, sorang, mufassir dapat mengetahui penjelasan kosa kata al-Qur'an, konotasi, dan konteksnya Kedua, Ilmu Nahwu (Tata Bahasa). Sebuah makna akan berubah seiring dengan perubahan I'rab. Oleh karena itu ilmu nahwu harus dikuasai. Ketiga, Ilmu Sharaf (Konyugrasi). Dengan ilmu ini, seorang mufassir dapat mengetahui bentuk asal dan pola (sighat) sebuah kata. Keempat, IIlmu Ma'ani (retorika). Dengan ilmu ini, seorang mufassir dapat mengetahui karakteristik susunan sebuah ungkapan dilihat dari makna yang dihasilkanya. Baca, Abd.Al-Hayy Al-Farmawi, Metode Tafsir Maudhu'I suatu pengantar, (Bandung CV Pustaka Sertisa, 2002), 20.

${ }^{32}$ Abdul Mustaqim, Dinamika Sejarah Tafsir Al-Qur'an, (Studi Aliran-aliran Tafsir dari Periode Klasik, Pertengahan hingga Moderen-Kontemporer) (Yogyakarta: Idea Prres, 2016), 87.

${ }^{33}$ Kementerian Agama RI, Al-Qur'an dan Terjemahan (Bandung: Mikraj Khazanah Ilmu, 2016), 77.
} 
dalam menafsirkan ayat tersebut cendrung ditafsirkan secara teks sehingga penafsiranya berimbas kepada poligami. ${ }^{34}$

Secara spesipik, penafsiran Ibnu Katsir juga mengacu kepada ilmu filsafat dalam arti cara menafsirkan ayat tersebut tidak terlepas dari kajian ontologi (objek kajian atau mahiyah), epistemology (cara perolehan ilmu atau pengetahuan), dan aksiologi (nilai kegunaan ilmu). Adapun tentang ontology ilmu tafsir telah dibahas pada bagian terdahulu, sedangkan epistemology tafsir dalam konteks ini adalah metode penafsiran al-Qur'an. ${ }^{35}$ Karena biasanya ulama klasik menafsirkan al-Qur'an sesuai tekstual berdasrkan hadits dan riwayat para sahabat lainya. ${ }^{36}$

Hemat penulis, penafsiran ayat poligami secara garis besar mengandung dua klasifikasi yaitu, Pertama, tafsir bil Ma'tsur dan tafsir ar-Ra'yi. Penafsiran terhadap alQur'an hanya mengacu kepada hadits dan pendapat para tabi'in. sehingga pemahamn terhadap al-Qur'an cendrung bersifat tekstual secara langsung tanpa menimbangi dasi sisi kontekstual sebagai bahan pertimbangan masyarakat. Dapat disimpulkan poligami dalam pandangan ulama klsik tetap saja di perbolehkan hal ini dipertegas dalam berbagai alas an baik dalam hadits maupun riwayat dari sahabat. karena konsep pologami selama mampu berbuat adil maka poligami tetap saja diperbolehkan.

\section{Kontekstualisasi Penafsiran Fazlur Rahman "Era Kontemporer"}

"Shifting Paradigm" dalam Dunia Tafsir untuk menyelesaikan dan menjawab tantangan modernitas. Tidak seperti karakteristik tafsir periode sebelumnya yang cenderung bersifat ideologis, repititif, dan parsial, karakteristik penafsiran modernkontemporer lebih bernuansa hermeneutis, ilmiah, kritis, nonsectarian,kontekstual, dan berorientasi pada spirit al-Qur'an. Mengungkapkan makna kontekstual dan berorientasi pada semangat al-Qur'an, merupakan karakteristik yang menonjol di era modernkontemporer ini. ${ }^{37}$

Penafsiran poligami di era kontemporer ini sudah tentun jelas berbeda, perbedaan tersebut dapat diketahui beberapa aspek terkait dengan pemahaman terhadap al-Qur'an, metodologi, dan model penafsiran al-Qur'an. Dalam pandangan rahman bahwa, al-Qur'an muncul dalam sinaran sejarah dan berhadapan dengan latar belakang sosio historis. Maka al-Qur'an perlu direspon terhadap situasi yang sebagian besarnya merupakan pernyataan-pernyataan moral, religius, yang menanggapi berbagai persoalan spesifik dalam situasi konkrit. ${ }^{38}$

${ }^{34}$ Imam Ibnu Katsir, Tafsir Al-Qur'an Al- Adzim, Jilid III, Cet. 1 (Surkarta: Insan Kamil, 2015), 232.

${ }^{35}$ Ahmad Izzan, Metodologi Ilmu Tafsir, Cet. III (Bandung: Tafakur, 2011), 103.

${ }^{36}$ Yayan Rahtikawati, Dadan Rusman, Metodologi Tafsir al-Qur'an (Strukturalisme, Semantik, Semiotik,, \& Hermeneutik) (Bandung: Pustaka Setia, 2013), 31.

${ }^{37}$ Abdul Mustaqim, Dinamika Sejarah Tafsir Al-Qur'an (Studi Aliran-aliran Tafsir dari Periode Klasik, Pertengahan, hingga Modern-Kontemporer), (Yogyakarta: Idea Press, 2016).

${ }^{38}$ Abdul Mustaqim, Syahiron Syamsudin, Studi al-Qur'an Kontemporer, (Yogyakarta: PT Tiara Wacana, 2002), 48. 
Dalam perspektif fazlurrahman menafsirkan ayat tersebut bukan ditafsirkan secara tekstual dalam konteks menafsirkan apa yang termuat dalam teks ayat al-Qur'an melainkan ada beberapa bahan pertimbangan bagi fazlurrahman dalam menafsirkan ayat tersebut. Lebih-lebih Rahman mereduksi keinginan Al-Qur'an itu sendiri, sebenarnya yang diinginkan Al-Qur'an sesungguhnya bukan praktik beristri banyak. Karena praktik ini tidak sesuai dengan harkat yang telah diberikan Al-Qur'an kepada wanita, status wanita yang selama ini cenderung disubordinasikan sebagai manusia nomor dua, dapat dikatakan besar kemungkinan praktik poligami tetap diberlakukan ${ }^{39}$. Jadi pesan yang terdalam Al-Qur'an tidak menganjurkan poligami melainkan Ia justru memerintahkan sebaliknya, monogami. Itulah ideal moral yang hendak dituju AlQur'an. ${ }^{40}$ Hal demikian, menunjukkan adanya sebuah pergeseran penafsiran ayat alQur'an baik dari konteks metode dan bentuk penafsiran dalam memahami ayat alQur'an.

Proses penafsiran al-Qur'an menurut rahman, maka dalam hal ini penulis akan memetakkan berupa langkah-langkah dan metode sehingga penafsiran al-Qur'an berbeda dengan periode masa klasik. Menurut rahman, al-Qur'an bukan hanya dipahami melaui kaidah-kaidah yang dibangun oleh para ulama-ulma klasik terdahulu. dalam kajianya yang begitu berkembang saat ini meahirkan berbagai macam pola pemikiran yang digagas oleh beberapa pemikiran-pemikiran kontemporer. Dalam hal ini ada beberapa pendekatan-pendekatan yang digagas oleh rahman dalam rangka menginterpretasikan ayat-ayat sesuai dengan pemahaman secara kontekstual dan memperhatikan tujuan sosial masyarakat diantaranya:

\section{Pendeketan Kontekstual Dalam Penafsiran}

Kehadiran Al-Qur'an bersifat kontekstual dan memiliki relevansi dalam kehidupan masyarakat saat itu. Terdapat hubungan yang dialektis anatara teks AlQur'an dan relaitas budaya. Meskipun Al-Qur'an diwahyukan oleh Tuhan, secara historis ia telah dan secara kultural berdialog dengan masyarakat arab. ${ }^{41}$ Maka dalam konteks penafsiran kontemporer mennggap bahwa al-Qur'an sebenarnya tetap eksis berbicara sesuai tempat dan waktu dengan istilah "shalihun likulli zamann wa makann" ditempat sesuai keadaan agar pemahaman terhadap al-Qur'an tidak berhenti sebatas teks melainkan perlu ditelusuri makna ayat al-Qur'an dibalik teks ayat tersebut. Jadi membaca teks, dalam pengertian memahaminya mengandung penafsiran dan penakwilanya. Pemahaman bersifat langsung, tanpa ,membutuhkan penafsiran atau penakwilan. Jika pemahaman lanngsung sulit maka hal ini salah satu metodologi yang

\footnotetext{
${ }^{39}$ Sibawaihi, Hermenutika Al-Qur'an Fazlurrahman, 75.

${ }^{40}$ Sibawaihi, Hermenutika Al-Qur'an Fazlurrahman, 77.

${ }^{41}$ Muhammad Chirzin, Fenomena Al-Qur'an 'Diskusi Pemikiran Ulil Absar-Abdalla, Lutfhi Assyaukhani, dan Abd Moqsith Ghazali tentang Metodologi Studi Al-Qur'an (Yogyakarta: Pustaka Pelajar, 2018), 225.
} 
akan dibutuhkan memahami dari tingkat kedua dengan berlandaskan pada logika bahasa, orientasi teks (konteks) keharusan sikap atau semangat zaman tersebut. ${ }^{42}$

Maka dalam penafsiran kontekstual dapat dikatakan sebagai proses interpretasi yang melalui hermeneutika. Hal ini menurut penulis, penting untuk di singgung dan dikaji teori hermeneutika dalam penafsiran. Metode tersebut dapat membeikan pemahaman baru dalam penafsiran al-Qur'an baik dalam konteks sejarah maupun konteks sosial. Karena hermeneutika mencoba mencari pemahaman terkiat dibalik teks ayat tersebut. Sejalan dengan kebutuhan dan tantangan akan suatu metode penafsiran yang bercorak kontekstual. Sebagaiamana dipandang bahwa, metode penafsiran cukup resrepentatif dan komprehensif untuk mengolah teks serta sangat intensif dalam menggarap kontekstualisasi. ${ }^{43}$

Dalam hal ini, al-Qur'an dapat diposisikan sebagai miotra dialog bagi para pembacanya yaitu dengan mengasumsikan bahwa teks al-Qur'an merupakan sosok pribadi mandiri, otonom, dan secara objektif memiliki kebenaran yang bisa dipahami secara rasional. Hal ini menunjukkan adanya keberlangsungan dan metode terbaru untuk berintraksi dengan al-Qur'an.

Sejarah mencatat bahwa pembacaan terhadap teks al-Qur'an telah dilakukan sejak pertamakali ia diturunkan, namun hingga kini, ide-ide segar tidak pernah kering mengalir dari celah-celah mata air terkait wahyu Tuhan ini. Keberagaman pendekatan dan metode yang digunakan berbanding lurus dengan pemahaman yang dihasilkan. Karena kajian al-Qur' an berbagai model apapun, baik berupa tafsir, ta'wil, interpretasi, ataupun terjemahan terhadap teks al-Qur'an merupakan wilayah hermeneutika yang sangat terbuka bagi setiap usaha pembaharuan terhadap pemahaman. ${ }^{44}$

\section{Tafsir Sebagai Transformasi Sosial}

Al-Qur'an secara universal bukan berbicara persoalan hukum akan tetapi alQur'an juga merupakan salah satu aspek yang mengandung nilai-nila moral dan keadilan untuk dipahami dalam teks penafsiran. Analisis penafsir juga berangkat dari fungsi kehadiran Al-Qur'an bagi umat Manusia. Dilihat beberapa tafsir era modernkontemporer cenderung memahami ayat tersebut lebih kepada persolan tehadap monogomi karena kehadiran Al-Qur'an kepada manusia antara lain untuk menegakkan keadilan. Persoalan keadilan adalah nilai utama yang yang diinginkan oleh AlQur'an.45 Ini artinya bahwa secara integral dan meneyeluruh pendekatan anaisis keilmuan untuk melakukan upaya untuk mencari makna teks perlu dipertimbangkan

\footnotetext{
${ }^{42}$ Hasan Hanafi, Hermeneutika Al-Qur'an, Penerjemah: Yudian Wahyudi, Hamdiah Latif (Yogyakarta: Pesantren Nawesea Press, 2009), 74-75.

${ }^{43}$ Fahruddin Faiz, Hermeneutika Al-Qur'an (Yogyakarta: Qalam, 2007), 8.

${ }^{44}$ Muhammad Syahrur, Prinsip dan Dasar Hermeneutika Al-Qur'an Kontemporer, Penerjemah: Sahiron Syamsuddin \& Burhanuddin (Yogyakarta: Elsaq Press, 2004), xvi.

${ }^{45}$ Baidowi, Memandang Perempuan, 27.
} 
konteks sosio kultural pada waktu itu dan konteks kekinian untuk melakukan kontekstualisasi terhadap ajaran Islam.46

Dengan demikian, ada beberapa karakteristik yang di gunakan pada era tafsir modern-kontemporer sebagai salah satu upaya untuk menginternalisasikan antara teks dengan realitas sosial yaitu:

1. Bagiamana mufassir secara adil mendefinisikan apa yang dipahami sebagai problem kemanusiaan. Bagaimana sebuah kerangka teori didefinisikan sebagai problem kemanusiaan.

2. Bagaimana memperlakukan teks dalam tahap refleksi kritis, teks diperlukan sebagai alat untuk mempertajam nurani dalammelihat problem kemanusiaan karena teks bukan satu-satunya rujukan dalam melakukan refleksi kritis.

3. Teks perlu direkontruksi dan metodologi baru untuk memahaminya, apalagi dalam melihat teks-teks yang berbicara kemanusiaan perlu dilihat secara kritis dan analisis penafsiran Al-Qur'an.47

Prinsip-prinsip yang dibangun oleh ulama tafsir modern-kontemporer sebenarnya untuk menemukan hakikat Al-Qur'an sehingga proses penafsiran tidak pernah terlepas dari sebuah konsep dasar untuk mencari tujuan dan nilai-nilai moral dalam Islam dikenal dengan Maqasid Syari'ah.48 Pendekatan-pendekatan dalam menafsirkan teks sangat dibutuhkan dalam pemikiran tafsir kekinian. Dapat diringkas, ada beberapa pandangan terhadap pendekatan ilmu sosial dalam menafsirkan Al-Qur'an sebagai berikut: Pertama, erlunya agar didapatkan penafsiran al-Qur'an yang sesuai dengan realitas sosial yaitu membangun teori-teori modern dalam penafsiran. Kedua, perlu agar didapatkan penafsiran Al-Qur'an yang sesuai dengan realitas sosial. Ketiga, Ilmu sosial sangat penting untuk memeberikan warna tersendiri dalam menafsirkan AlQur'an dan mampu hidayah sebagi bentuk perubahan serta dapat memberikan berbagai informasi dan hal lain yang diungkapkan oleh al-Qur'an.

Contoh Penafsiran Fazlur Rahman Q.S Al-maidah [5]: 38)
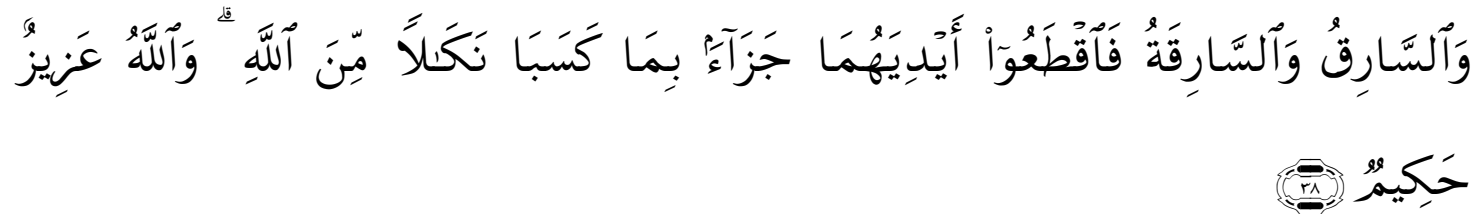

Artinya : "Laki-laki yang mencuri dan perempuan yang mencuri, potonglah tangan keduanya (sebagai) pembalasan bagi apa yang mereka kerjakan dan sebagai siksaan dari Allah. dan Allah Maha Perkasa lagi Maha Bijaksana”. (Q.S Almaidah [5]: 38). ${ }^{49}$

\footnotetext{
${ }^{46}$ Abdul Mustaqim, Pradigma Tafsir Feminis "Membaca Al-Qur'an Dengan Optik Perempuan Dalam Pemikiran Riffat Hasan Tentang Isu Gender Dalam Islam” (Yogyakarta: Logung Pustaka), 109.

${ }^{47}$ Mansur, Metodologi Tafsir Kontemporer, 24.

${ }^{48}$ Jasser Auda, Membumikan Hukum Islam Melalui Maqasid Syariah (Bandung: PT Mizan Pustaka, 2015), 56.

${ }^{49}$ Kementerian Agama RI, Al-Qur'an dan Terjemahan, 92.
} 
Adapun sebab turunya ayat diatas adalah Imam Ahmad dan yang lainya meriwayatkan dari Abdullah bin Amr, dia menuturkan: pada zaman Rasulullah Saw, ada seorang perempuan yang melakukan pencurian sebagai hukumanya, tangan kanan wanita itu dipotong. ${ }^{50}$ Hukum potong tangan ini sendiri sudah berlaku sejak zaman jahiliyah, mereka memotong seorang tangan laki-laki yang bernama Duwaik, mantan hamba sahaya Bani Malih bin Amr bin Khuza'ah karena telah mencuri harta simpanan di Ka'bah. Sebagaian ulama ahli zahir mengatakan, seorang pencuri harus dipotong tanganya, berapapun harta yang dicuri, sedikit atau banyak berdasarkan keumuman ayat tersebut. Mereka sama sekali tidak menetapkan adanya (syarat) nisab maupun hirz. Akan tetapi mereka menetapkan potong tangan selama ada pencurian. ${ }^{51}$

Sehingga dalam hal ini, Ramhan berkontribusi dalam menafsirkan kata ( $f a-$ qtha'u) yang berarti potonglah tangan keduanya sebagai bentuk perintah untuk menghalangi tangan-tangan pencuri perbaikan ekonomi. Sehingga yang menjadi ideal moral dalam kasus ini adalah memotong kemampuan pencuri agar tidak mencuri lagi. Sebagaimana dua kasus diatas, praktik hukuman potong tangan bagi pencuri telah dilaksanakan dikalangan suku-suku Arab sebelum Islam.

Jika kita mencermati ayat tersebut berdasakan sosol historis, mencuri menurut kebudayaan mereka dianggap tidak saja sebagai kejahatan ekonomi, tetapi lebih sebagai kejahatan melawan nilai-nilai dan harga diri manusia. Namun, seiring dengan perkembangan kebudayaan manusia, mencuri dalam masyarakat urban telah mengalami pergeseran pemahaman. Pencuri dalam konsep modernitas tidak lebih dari sekedar kejahatan dalam bidang ekonomi yakni penghilangan hak milik seseorang oleh orang lain secara tidak sah belaka.

Pencurian saat ini tidak ada hubunganya dengan pelecehan terhadap harga diri manusia. Ini semata-mata tindak kriminal yang murni yang tidak dimotivasi oleh pelanggaran terhadap harga diri seseorang. Sehingga dalam berbagai pemikiran kontemporer maka hal ini yang menjadi dasar perlu adanya rekontrusi dan menafsirkan kembali terhadap pergeseran pemahaman nyata tentang definisi pencuri ini memerlukan perubahan bentuk hukum.

Bagi rahman, ayat diatas juga diniscayakan untuk diberlakukan ideal moralnya, yaitu memotong kemampuan sang pencuri untuk mencuri lagi bisa dilakukan dengan berbagai cara yang lebih manusiawi. Demikian cara kerja rahman dalam menafsirkan teks ayat-ayat al-Qur'an menggunkan istilah hermenutika yang dimaan hermenutika lebih menekan pada aspek kontekstualisasi dengan didukung sisiol historisnya.

Dengan demikian, Dengan demikian, untuk melakukan proses penafsiran AlQur'an dan melihat respon Al-Qur'an terhadap masyarakat dengan cara menghidupakan kembali pemabaharuan pemikiran Islam atau intlektual dengan melalui reinterpretasi dengan melihat ilmu sosial modern yang berkembang serta melihat realitas sosial empirik yang dihadapi. Maka penafsiran Al-Qur'an harus dihadapkan

\footnotetext{
${ }^{50}$ Imam As-Suyuthi, Asbabun Nuzul Qur'an ( Jawa Tengah: Insan Kamil, 2016), 225.

${ }^{51}$ Imam Ibnu Katsir, Tafsir Al-Qur'a Al-Azim (Jawa Tengah: Insan Kamil, 2015), 923.
} 
dengan realitas empirik yang dihadapi.52 Nuasa sosial kemasyarakatan yang di maksud di sini adalah tafsir yang menitik beratkan penjelasan ayat Al-Qur'an dari beberapa aspek yang harus diperhataikan di antaranya, 1) Segi ketilitian redaksinya, 2) kemudian menyususn kandungan ayat-ayat tersebut dalam suatu redaksi dengan tujuan utama untuk memaparkan tujuan al-Qur'an dan menggali nilai-nilainya, 3) Penafsiran al-Qur'an pada prinsipnya dikaitkan dengan sunnatullah yaitu berlaku dalam masyarakat.53

Oleh Karenanya, "Shifting Paradigm" dalam Dunia Tafsir untuk menyelesaikan dan menjawab tantangan modernitas. Tidak seperti karakteristik tafsir periode sebelumnya yang cenderung bersifat ideologis, repititif, dan parsial, karakteristik penafsiran modern-kontemporer lebih bernuansa hermeneutis, ilmiah, kritis, nonsectarian,kontekstual, dan berorientasi pada spirit al-Qur'an. Mengungkapkan makna kontekstual dan berorientasi pada semangat al-Qur'an, merupakan karakteristik yang menonjol di era modern-kontemporer ini. ${ }^{54}$

\section{Analisis Struktur Shifting Paradigma Dalam Orientasi Tafsir Qur'an}

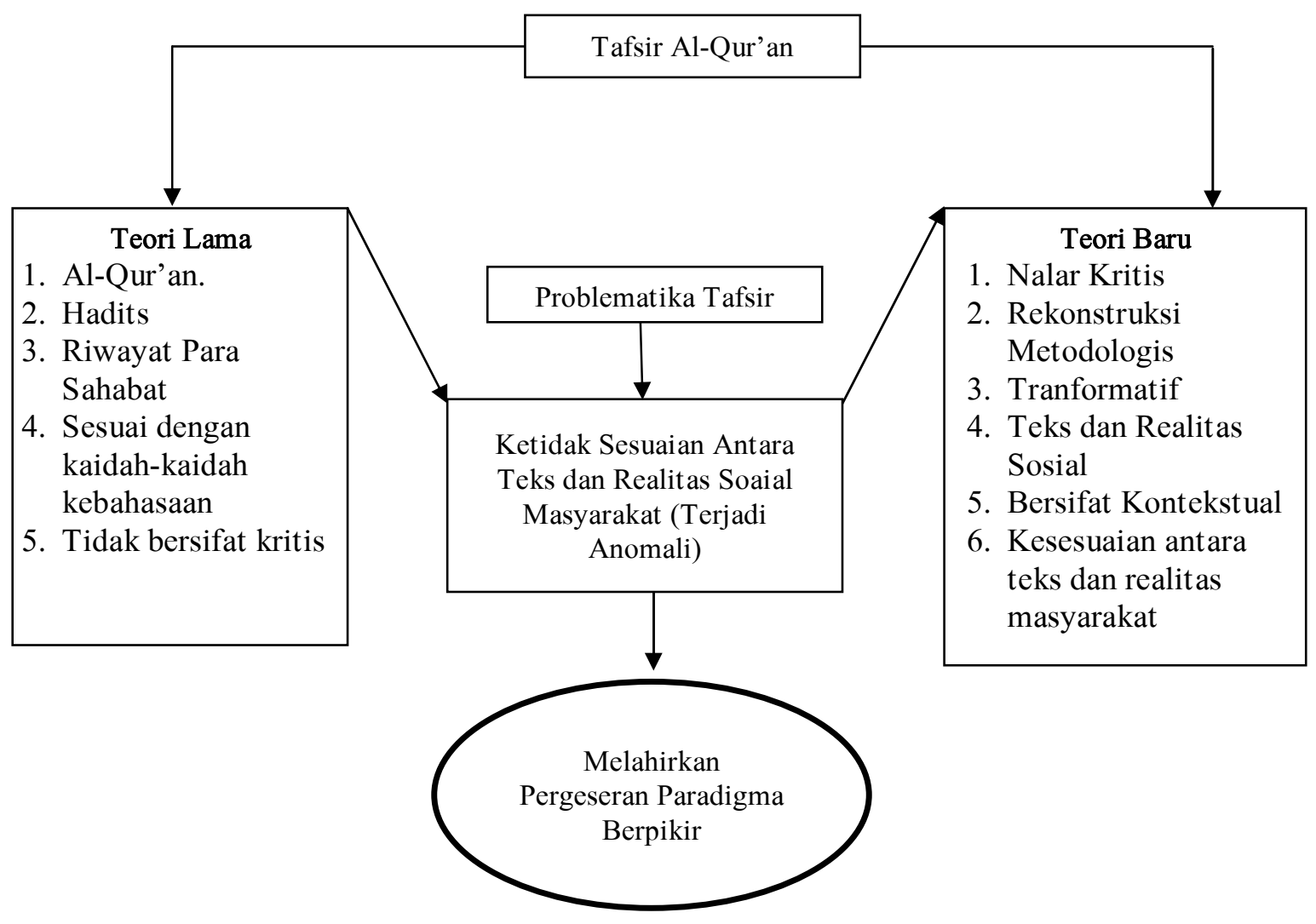

${ }^{52}$ Lestari, Genealogi Pemikiran Modern Dalam Islam (Mataram: Insan Madani Institute Mataram, 2016), 1.

${ }^{53}$ Islah Gusmian, Khazanah Tafsir Indonesia, 259.

${ }^{54}$ Abdul Mustaqim, Dinamika Sejarah Tafsir Al-Qur'an (Studi Aliran-aliran Tafsir dari Periode Klasik, Pertengahan, hingga Modern-Kontemporer), (Yogyakarta: Idea Press, 2016). 
Hemat penulis, shifting paradigm merupakan salah satu yang menyebabkan proses berkembang terhadap penafsiran. Sebagaimana di era modern-kontemporer pradigma berpikir lebih menekankan pada aspek sosial yang melingkupi sipenafsir seperti yang telah dipaparkan diatas, sebenarnya keterkaitan antara pemahaman sosial historis dengan teori ini yang mencakup tentang pemahaman sekarang atau situasi dan kondisi yang melingkupi para penafsir kontemporer saat ini. Untuk itu dalam mengungkapkan pesan-pesan teks supaya objektif sebenarnya dituntut untuk meningglakan pra-pemahaman dalam arti pemahaman terhadap teks ayat-ayat alQur'an harus berdasarkan probem yang dihadapi saat ini (konteks mempunyai konteks tersendiri), maka untuk menafsirkan dan memahami teks diperlukan kajian sosial dimana teks tersebut muncul dalam tahap aplikasi Rahman juga tidak menggunakan makna literal teks tapi ideal moral dari teks tersebut.

\section{Penutup}

Berdasarkan hasil analisis dalam lintasan kajian tafsir pada era klasik dan kontemporer telah menunjukkan adanya terjadi pergeseran "Shifting Paradigma” yaitu pergeseran dan perkembangan konsep berpikir menjadi suatu hal yang sangat kritis ketika para mufassir mencoba mendialogkan antara teks dan realitas. Ibn katsir seperti biasanya ketika menafsirkan Al-Qur'an orientasi tafsirnya didasarkan pada hadits, riwayat-riwayat para sahabat dan kesesuaian kaidah-kaidah Bahasa. Namun demikian, Fazlurrahman berkecemderungan ketika memahami Al-Qur'an bukan berkutat pada hadits dan riwayat-riwayat para sahabat, akan tetapi dalam pengkajian Al-Qur'an lebih melihat pada aspek realitas sosial sehingga dapat memunculkan nalar yang kritis yaitu Pergeseran "shifting paradigma" memunculkan teori dengan memperhatikan metodologis, keragaman pendekatan keilmuan, memahami teks secara kontekstual, dan tafsir sebagai salah satu untuk mencari keadilan sehingga menjawab berbagai tantangan problematika sosial. Sebagaimana dalam kajian diatas telah dikaji melaui perbandingan penafsirannya tersebut. 


\section{DAFTAR PUSTAKA}

Wely Dozan, Epistemologi Tafsir Klasik: Studi Analisis Pemikiran Ibnu Katsir, Jurnal: Falasifa, Vol.10.No.1, 2019.

Munawwir Husni, Studi Keilmuan Al-Qur'an, Yogyakarta: Binafsi Publisher, 2015.

Ahmad Fadlol dkk, Studi Al-Qur'an Teori dan Metodologi, Yogyakarta: Idea Press, 2011.

Wely Dozan, Hermeneutika Sebagai Metode Penafsiran Al-Qur'an: (Melacak Teori Hermeneutika Fazlurrahman), Jurnal: El-Hikam, Volume XII, Nomor 1, Januari -Juni 2019.

Ahmad Zaki Mubarok, Pendekatan Strukturalisme Linguistik Dalam Tafsir al-Qur'an Kontemporer"ala" Muhammad Ayahrur, Yogyakarta: Elsaq Press, 2007.

Abdul Mustaqim, Dinamika Sejarah Tafsir Al-Qur'an "Studi Aliran-Aliran Tafsir Dari Periode Klasik Hingga Kontemporer” Yogyakarta: LSQ Ar-rahmah.

Rohimi, Metodologi Ilmu Tafsir \& Aplikasi Model Penafsiran, Yogyakarta: Pustaka Pelajar, 2007.

Yayan Rahtikawati, Dadan Rusman, Metodologi Tafsir Al-Qur'an 'Struturalisme, Semantik, Semiotik, \& Hermeneutik, Bandung: Pustaka Setia, 2013.

Yunus Hasan Abidu, Tafsir Al-Qur'an (Sejarah Tafsir dan Metode Para Mufassir), Jakarta: GAYA MEDIA PRATAMA, 2007.

Abd. Al-Hayy Al-Farmawi, Suatu Pengantar Metode Tafsir Maudhu'I, Bandung: Pustaka Setia, 2002.

Abdul Mustaqim, Metode penelitian al-Qur'an dan Tafsir, Yogyakarta: Idea Press, 2012.

Usman, Ilmu Tafsir, Yogyakarta: Teras, 2009.

Ahmad Izzan, Metodologi Ilmu Tafsir, Tafakkur: Humaniora, 2011.

Mansur, Metodologi Tafsir Kontemporer, (Menimbang Tawaran Metodologi Tafsir Emansipatoris), Yogyakarta: Interpena, 2011

Taufik Adnan Rahkmat, Islam dan Tantangan Modernitas (Studi atas Pemikiran Hukum Fazlurrahman), Bandung: Mizan, 1989.

Abdullah Saed, Al-Qur'an Abad 21 “Tafsir Kontekstual', Bandung: Mizan, 2016.

Hasan Hanafi, Hermeneutika Al-Qur'an, Penerjemah: Yudian Wahyudi, Hamdiah Latif, Yogyakarta: Pesantren Nawesea Press, 2009.

Fahruddin Faiz, Hermeneutika Al-Qur'an, Yogyakarta: Qalam, 2007.

Rohimi, Metodologi Ilmu Tafsir dan Aplikasi Model Penafsiran, Yogyakarta: Pustaka Pelajar, 2007.

Kementerian Agama RI, Al-Qur'an dan Terjemahan, Bandung: Mikraj Khazanah Ilmu, 2016.

Imam Ibnu Katsir, Tafsir Al-Qur'an Al-Adzim, Jilid III Surkarta: Insan Kamil, Cet. 1, 2015.

Abdul Mustaqim, Syahiron Syamsudin, Studi al-Qur'an Kontemporer, Yogyakarta: PT Tiara Wacana, 2002.

Sibawaihi, Hermenutika Fazlurrahman, Yogyakarta: Jalastura, 2007.

Mu'ammar Zayn Qadafy, Asbabun Nuzul Dari Mikro Hingga Makro (Sebuah Kajian Epistemologis seri Ulumul Qur'an Kontemporer), Yogyakarta: Azna Books, 2015.

Syahiron Syamsuddin, Hermeneutika Al-Qur'an Dan Hadits, Yogyakarta: Elsaq Press, 2010. 
Amin Abdullah, Metode Kontemporer Dalam Tafsir Al-Qur'an : Kesalingketerkaitan Asbabun Al-Nuzul Al-Qadim Dan Al-Jadid Dalam Tafsir Al-Qur'an Kontemporer, Dalam Jurnal Studi Ilmu-Ilmu Al-Qur'an Dan Hadits, (Jurnal: Vol.13, No.1 Januari2012.

Abdul Fatah Abdul Gharu al-Qadhi, Asbab al-Nuzul 'an al-Shababah wa al-Mufassirin (Mesir: Dar al-Salam, 2005.

Ahmad Syukri, Metodologi Tafsir Al-Qur'an Kontemporer Dalam Pandangan

Thomas S. Kuhn, The Structure of scientefic Revolution, Chicago: Univesity of Chicago Press, 1996

Rohimi Metodologi Ilmu Tafsir \& Aplikasi Model Penafsiran, Yogyakarta: Pustaka Pelajar, 2007

Zubaidi, Filsafat Barat "Dari Logika Baru Rene Descartes hingga Revolusi Sains ala Thomas Khun, Jogjakarta: AR-RUZZ MEDIA, 2007

Siti Robikah, Shifting Paradigm Dalam Tafsir Al-Quran ; Analisis Terhadap Perkembangan Tafsir Feminis Di Indonesia, Jurnal: Tafsere Volume 7 Nomor 2 Tahun 2019

Muhammad Chirzin, Fenomena Al-Qur'an "Diskusi Pemikiran Ulil Absar-Abdalla, Lutfhi Assyaukhani, dan Abd Moqsith Ghazali tentang Metodologi Studi Al-Qur'an, Yogyakarta: Pustaka Pelajar, 2018

Hasan Hanafi, Hermeneutika Al-Qur'an, Penerjemah: Yudian Wahyudi, Hamdiah Latif, Yogyakarta: Pesantren Nawesea Press, 2009

Muhammad Syahrur, Prinsip dan Dasar Hermeneutika Al-Qur'an Kontemporer, Penerjemah: Sahiron Syamsuddin \& Burhanuddin, Yogyakarta: Elsaq Press, 2004

Abdul Mustaqim, Pradigma Tafsir Feminis "Membaca Al-Qur'an Dengan Optik Perempuan Dalam Pemikiran Riffat Hasan Tentang Isu Gender Dalam Islam", Yogyakarta: Logung Pustaka.

Jasser Auda, Membumikan Hukum Islam Melalui Maqasid Syariah, Bandung: PT Mizan Pustaka, 2015.

Imam As-Suyuthi, Asbabun Nuzul Qur'an, Jawa Tengah: Insan Kamil, 2016.

Lestari, Genealogi Pemikiran Modern Dalam Islam, Mataram: Insan Madani Institute Mataram, 2016.

Abdul Fatah Abdul Gharu al-Qadhi, Asbab al-Nuzul 'an al-Shababah wa al-Mufassirin Mesir: Dar al-Salam, 2005. 